Acta Universitatis Wratislaviensis No 4052

PRAWO CCCXXXII

Wrocław 2021

https://doi.org/10.19195/0524-4544.332.1

WOJCIECH RUDNIK

ORCID: 0000-0001-7176-1550

Uniwersytet Mikołaja Kopernika w Toruniu

w.rudnik17@gmail.com

\title{
Pojęcie karalnego usiłowania w doktrynie oraz ustawodawstwie miast włoskich (XIII-XIV wiek)
}

Opracowanie niniejsze opiera się w dużej części na krajowej i zagranicznej literaturze przedmiotu oraz w mniejszym stopniu na dostępnych materiałach źródłowych. Pociąganie do odpowiedzialności karnej za przestępny zamiar, chociażby nie doszedł do skutku, jest jedną z cech charakterystycznych rozwiniętych systemów prawnych. Współczesna instytucja usiłowania wiąże się z dążeniem do wypełnienia znamion określonego czynu zabronionego. Początki takiego rozumowania, jeszcze przed epoką nowożytną, znaleźć można w statutach, czyli zbiorach przepisów prawnych tworzonych przez średniowieczne miasta włoskie w okresie, w którym przyjęły one specyficzną formę ustrojową komun. Aby zrozumieć, w jakich warunkach tworzyły się nowe koncepcje prawne, warto pokrótce przedstawić historię komuny włoskiej.

\section{Komuna włoska ${ }^{1}$}

Miasta Italii w czasach wczesnego średniowiecza odznaczały się szczególnym rozwojem na tle ośrodków miejskich pozostałej części Europy. Na przełomie

${ }^{1}$ W literaturze polskiej szerzej na temat genezy i ewolucji ustroju komun miejskich we Włoszech zob. m.in. J. Ptaśnik, Miasta i mieszczaństwo w dawnej Polsce, Kraków 1934, s. 1-29; J.A. Gierowski, Historia Włoch, Wrocław-Warszawa-Kraków-Gdańsk-Łódź 1986, s. 102-115, 124-143, 162-168; H. Manikowska, Średniowieczne miasta-państwa na Półwyspie Apenińskim, [w:] Rozkwit średniowiecznej Europy, red. H. Samsonowicz, Warszawa 2001, s. 250-377; K. Koranyi, Powszechna historia państwa i prawa, t. 3, Warszawa 1966, s. 73-83; T. Maciejewski, Historia powszechna państwa i prawa, Warszawa 2000, s. 203-209; K. Kamińska, A. Gaca, Historia powszechna ustrojów państwowych, Toruń 2011, s. 247-259.

Prawo Studia historycznoprawne 332, 2021

(C) for this edition by CNS 
XI i XII wieku pierwsze z nich uniezależniły się od władzy monarszej i uzyskały autonomię ${ }^{2}$. Miejsce biskupów, zarządzających dotychczas miastami w imieniu cesarza, zajęli konsulowie. Określenia tego nie należy wiązać z konsulami antycznego Rzymu, byli to urzędnicy swoistego typu, w pewnym stopniu odpowiadający radnym miejskim ${ }^{3}$. Liczba konsulów wynosiła w zależności od miasta od dwóch do nawet 20, wybierani byli zazwyczaj na jednoroczną kadencję przez zgromadzenie obywateli (consio) w głosowaniu dwustopniowym. Do ich kompetencji należało między innymi sprawowanie wymiaru sprawiedliwości ${ }^{4}$.

Wraz z powołaniem pierwszych konsulów wykształciła się specyficzna forma komuny. Pod pojęciem tym należy rozumieć wspólny związek wszystkich mieszkańców, wśród których wyróżnić można szlachtę, kupców, rzemieślników, duchowieństwo itd. Cesarz Fryderyk Barbarossa próbował przywrócić swoje zwierzchnictwo, lecz poniósł porażkę i poprzez pokój w Konstancji z 1183 roku potwierdził niezależność miast północnej Italiii ${ }^{5}$.

Od końca XII do drugiej połowy XIII wieku miał miejsce kolejny etap rozwoju komuny, zwany okresem podesty. Z powodu podziału wewnątrz komuny na wrogie sobie frakcje i nasilających się walk pomiędzy zwaśnionymi rodami bądź klasami społecznymi podjęto decyzję o zastąpieniu konsulów jednym urzędnikiem pochodzącym z innego miasta, który miał zagwarantować bezstronność. Podesta sprawował najwyższą władzę wykonawczą i sądowniczą, a jego kadencja trwała krótko. Ten elekcyjny urzędnik, który niejednokrotnie sam miał wykształcenie prawnicze, każdorazowo sprowadzał ze sobą do miasta jurystów uczonych w prawie rzymskim i kanonicznym ${ }^{6}$. Cechą charakterystyczną tego okresu były bardzo częste nowelizacje statutów. Instytucja podesty, chociaż przyczyniła się do rozwoju ustawodawstwa, nie zażegnała konfliktów targających komunami ${ }^{7}$.

Po roku 1250 obok gminy podesty powstał osobny samorząd rzemiosł, na czele którego stał tak zwany kapitan ludu (il capitano del popolo) reprezentujący interesy kupców i rzemieślników zgrupowanych w cechy. W niektórych miastach (na przykład Florencja) przejął pełnię władzy. Kres rozwoju autonomicznej komuny nastąpił pod koniec XIV stulecia, gdy rządy objęli signorowie, czyli tyrani zakładający nowe dynastie arystokratyczne ${ }^{8}$.

2 A. Padoa-Schioppa, Il diritto nella storia d'Europa. Il medioevo, t. 1, Mediolan 2005, s. 419.

3 M. Patkaniowski, Charakterystyka ustawodawstwa statutowego na tle rozwoju komuny wtoskiej, „Czasopismo Prawnicze” 31, 1938, s. 131.

${ }^{4}$ F. Calasso, Medio evo del diritto: I - de fonti, Mediolan 1954, s. 261.

5 A. Padoa-Schioppa, op. cit., s. 205.

${ }^{6}$ M. Patkaniowski, op. cit., s. 140.

7 A. Padoa-Schioppa, op. cit., s. 214.

8 Jedną z ostatnich publikacji poświęconych dalszemu rozwojowi miast włoskich jest: A. Jurkowska-Zeidler, K. Zeidler, Medyceusze jako bankierzy oraz mecenasi i kolekcjonerzy sztuki, [w:] Miasto i państwo na przestrzeni dziejów, studium historyczno-prawne: księga jubileuszowa z okazji czterdziestopięciolecia pracy naukowej oraz 70. urodzin profesora Tadeusza Maciejewskiego, red. M. Gałędek, Warszawa 2020, s. 25-34. 


\section{Statuty}

W doktrynie średniowiecznej pojawily się dwie teorie dotyczące kompetencji miast do wydawania statutów (potestas statuendi) ${ }^{9}$. Wszakże dotychczas za źródła prawa uznawano jedynie zwyczaj i ustawy cesarskie. Teoria przyzwolenia (permissio) zakładała, że zgody udzielił cesarz, wyrażając ją przede wszystkim w traktacie z Konstancji. Popierał ją Albertus Gandinus. Teoria jurysdykcji, wypracowana przez Bartolusa de Saxoferrato, opierała się na założeniu, że możliwość regulacji statutowej wynika z samej istoty prawa powszechnego (ius commune), którego swoistym przejawem w komunach są statuty. Stąd pojęcie statutum jako ustawy partykularnej obowiązującej na małej przestrzeni w przeciwieństwie do lex, które rozumiano jako ustawę uniwersalną i podstawową dla innych aktów ${ }^{10}$.

Na statut, czyli kodeks miejski, złożyły się trzy elementy: wcześniej spisywane już zwyczaje (consuetudines), teksty przysiąg składanych przez konsulów w momencie obejmowania urzędu dotyczące sprawowania władzy (brevi) oraz uchwały podejmowane przez zgromadzenie obywateli ${ }^{11}$. Za opracowanie tej kompilacji odpowiadały specjalnie powoływane przez gminę osoby, zwane statutarii (reformatores, correctores) ${ }^{12}$. Często byli to doświadczeni prawnicy, chociażby wybitny glosator boloński Jacopo Baldovini, któremu powierzono opracowanie statutu w Genui, w czasie, gdy sprawował w tym mieście urząd podesty ${ }^{13}$. Duże znaczenie przy ich tworzeniu odgrywał czynnik społeczny, każdy mógł zgłosić własne propozycje dotyczące regulacji. Kodyfikacja podlegała zatwierdzeniu przez odpowiednie ciało ustawodawcze. Statut dzielono na kilka ksiąg, z których zazwyczaj trzecia dotyczyła prawa karnego ${ }^{14}$. Większość tych aktów spisano w języku łacińskim. Gdy mówi się o statutach, zazwyczaj dotyczy to prawa miast północnych Włoch. W Italii południowej, na terenie Królestwa Sycylii, ustawodawstwo miejskie również powstało, jednak w bardziej ograniczonym zakresie, z powodu wymogu zgodności z prawodawstwem monarchy ${ }^{15}$.

\section{Elementy rzymskie i longobardzkie}

Jak słusznie zauważył Michał Patkaniowski, największy wpływ na kształtowanie się ustawodawstwa statutowego wywarły elementy prawa longobardzkiego

9 Storia del diritto medievale e moderno, red. R.M. Venittelli, Neapol 2002, s. 124.

10 A. Padoa-Schioppa, Storia del diritto in Europa. Dal medioevo all'età contemporanea, Bolonia 2007, s. 197.

11 M. Caravale, Ordinamenti giuridici dell'Europa medievale, Bolonia 2003, s. 98.

12 F. Calasso, op. cit., s. 488.

13 A. Padoa-Schioppa, Storia..., s. 174.

14 Ibidem, s. 426.

15 Por. M. Patkaniowski, op. cit., s. 120-121. 
i rzymskiego. Ustawy Longobardów, panujących w Italii od VI do VIII wieku, odznaczały się najlepszą techniką legislacyjną wśród praw barbarzyńskich. Profesorowie uczelni w Pawii, najznakomitszej jedenastowiecznej szkoły prawa, przyczynili się do popularyzacji leges langobardorum, porównując je z przepisami Instytucji Justyniana ${ }^{16}$.

W prawie germańskim aspekt subiektywny przestępstwa co do zasady nie odgrywał znaczącej roli, zwracano uwagę przede wszystkim na obiektywny skutek wywołany w świecie rzeczywistym, aczkolwiek prawo longobardzkie w pewnym stopniu rozróżniało już stronę podmiotową. Pojęcie usiłowania z całą pewnością nie było jeszcze rozwinięte, natomiast ustawodawstwo longobardzkie zawierało kilka przepisów, w których karane były już czynności przygotowawcze jako osobne przestępstwo (delictum sui generis) ${ }^{17}$.

Przepis $§ 139$ Edyktu Rotara ${ }^{18}$ stanowił, iż jeśli człowiek wolny sporządziłby truciznę i chciał ją dać innemu do wypicia, płacił 20 solidów, tak jak ten, kto powziął consilium mortis. Ostatnie pojęcie należało interpretować w znaczeniu szerokim, obejmującym zarówno voluntas occidendi, jak i działania, które stanowiły pierwszy przejaw celu dokonania zabójstwa ${ }^{19}$. Następny przepis Edyktu Rotara odnosił się do sytuacji, gdy podanie trucizny się udało, lecz dany człowiek od niej nie umarł. Wówczas truciciel musiał zapłacić swojej niedoszłej ofierze kwotę w wysokości główszczyzny.

Interesującą dyspozycję prezentował przepis $§ 1$ Edyktu Rotara. Groźbą kary śmierci i konfiskaty mienia zagrożony był każdy, kto by myślał lub spiskował przeciwko królowi. Penalizacja samego zamysłu stanowiła duży problem dla praktyki i doktryny średniowiecznej. $\mathrm{Z}$ tego względu w romanizującej glosie do Liber Papiensis, to jest zbioru ustaw longobardzkich, pojawił się komentarz do tego przepisu objaśniający, w jaki sposób poznaje się myśl ${ }^{20}$. Podano dość kazuistyczne przykłady wskazujące na uzewnętrznienie się powziętego zamiaru, takie jak znalezienie zamachowca ukrytego za drzwiami w komnacie króla z obnażonym mieczem schowanym pod płaszczem lub sztyletem w rękawie; sporządzenie trucizny przez cześnika posługującego królowi przy stole czy wyjawienie planu przez któregoś z członków spisku.

Prawo rzymskie, chociaż element subiektywny był w nim szeroko rozwinięty, również nie znało usiłowania karalnego (conatus), czego dowodził Contardo

16 S. Estreicher, Historia prawa zachodnio-europejskiego: źródła, Kraków 1946, s. 25.

17 M. Patkaniowski, Wina i kara. Elementy rzymskie i germańskie w prawie karnym statutów włoskich, Kraków 1939, s. 83.

18 Edykt Rotara (Edictus regis Rothari), ogłoszony w 643 roku, był pierwszym oficjalnym zbiorem prawa longobardzkiego. Zob. K. Koranyi, Powszechna historia państwa i prawa, t. 2, cz. 1, Warszawa 1963, s. 85-105.

19 A. D'Anello, La rilevanza degli atti preparatori in materia penale, Neapol 2013, s. 25.

20 M. Patkaniowski, Wina..., s. 83. 
Ferrini ${ }^{21}$. Ogólną zasadę rzymskiego prawa karnego wyrażała paremia sformułowana w III wieku przez Ulpiana - Cogitationis poenam nemo patitur, zgodnie z którą nikogo nie karze się za myśli, których realizacji nie podjęto. Zdarzały się jednak przypadki o charakterze wyjątku, w których penalizowano określone czynności przygotowawcze ${ }^{22}$. Przykładem były trzy akty prawne okresu klasycznego: Lex Cornelia de sicariis et veneficis, Lex Pompeia de parricidiis i Lex Iulia maiestatis. Pierwsza ustawa przewidywała sankcję w przypadku złapania bandyty, który grasował z bronią (cum telo ambulaverit) z zamiarem dokonania morderstwa lub rozboju oraz karała sporządzanie, posiadanie, sprzedaż, kupno i podanie trucizny (venenum $)^{23}$. Jeden z przepisów Lex Pompeia odnosił się do zakupu trucizny w celu uśmiercenia ojca. Paulus w komentarzu do Lex Iulia stwierdził, że już ten, kto podjął decyzję o dokonaniu zbrodni obrazy majestatu i był świadomy grożącej kary, nie mógł wyzwolić niewolnika.

Zatem ustawodawcy rzymscy dopuszczali opcję karania zamiaru jedynie jako swoiste działanie prewencyjne, mające na celu przeciwdziałanie sytuacjom szczególnie niebezpiecznym z punktu widzenia społecznego oraz czynom naznaczonym silnym oczekiwaniem na wystąpienie przestępnego skutku ${ }^{24}$.

\section{Teoria usiłowania}

Doktryna o maleficium cogitatum, flagitium imperfectum czy conatus została przez ustawodawstwo miejskie po raz pierwszy sformułowana niezależnie od idei rzymskich ${ }^{25}$. W prawie statutowym na szeroką skalę wykształciły się subiektywne przesłanki odpowiedzialności karnej. Uznanie strony podmiotowej przestępstwa za czynnik wpływający na zakres karalności było zapewne najważniejszym wkładem doktryny i praktyki komun włoskich w historię prawa karnego ${ }^{26}$. Całkowicie zerwano z germańską zasadą, że o winie decyduje wyłącznie skutek zewnętrzny.

21 P. Sadowski, Rzymskie prawo karne w ujęciu Contarda Ferriniego, „Studia Prawnoustrojowe" 2007, nr 7, s. 97.

22 A. D'Anello, op. cit., s. 15.

${ }^{23}$ Szerzej na ten temat K. Amielańczyk, Lex Cornelia de sicariis et veneficis. Ustawa Korneliusza Sulli przeciwko nożownikom i trucicielom, Lublin 2011. Autor zaznacza, że kryminalizacja czynów określanych jako crimen inter sicarios oraz veneficium miała charakter prewencyjny, a dobrem chronionym był porządek i bezpieczeństwo publiczne. Przestępstwa stypizowane w Lex Cornelia nie stanowiły zatem w żadnym stopniu form stadialnych zabójstwa, które wszakże często było ich skutkiem.

24 A. D'Anello, op. cit., s. 16.

25 G. Salvioli, Manuale di storia del diritto italiano: dalle invasione germaniche ai nostri giorni, Rome-Torino-Neapol 1890, s. 558.

${ }^{26}$ K. Sójka-Zielińska, Historia prawa, Warszawa 1986, s. 181. 
Statuty zwracają uwagę na nastawienie woli sprawcy, dla przyjęcia umyślności wymagają świadomości i przewidywania ${ }^{27}$.

Wzięto bowiem pod uwagę możliwość, że sprawca mógł dochować wszelkiej staranności w realizacji swojego voluntas sceleris, a skutek mógł nie nastąpić z przyczyn zupełnie niezależnych od niego. Powołano się również na autorytet prawa rzymskiego, przypominając dawną rzymską regułę sformułowaną w reskrypcie cesarza Hadriana - In maleficiis voluntas spectatur, non exitus („Przy przestępstwach patrzy się na wolę, a nie rezultat” ${ }^{28}$. Z tego powodu bardzo często za usiłowanie groziła taka sama kara jak za przestępstwo, do którego przedsięwzięte działanie było rzeczywistym wstępem, aczkolwiek w praktyce zazwyczaj wymierzano karę złagodzoną, chyba że sprawca usiłował violenter (gwałtownie $)^{29}$. Sformułowano ponadto własną zasadę, wyrażającą się w sentencji Punitur affectus etiam si non sequitur effectus („,Karze się także zamiar, jeśli nie doprowadzi do skutku").

Instytucja karalnego usiłowania była oryginalnym wytworem ustawodawstwa i judykatury średniowiecznych miast włoskich. Czerpiąc materiał ze źródeł longobardzkich i rzymskich, komuny wypracowały własne rozwiązanie. Konstrukcja usiłowania ustaliła się jako działanie skierowane ku urzeczywistnieniu złego zamiaru, które jednak nie odniosło skutku dzięki przypadkowi lub interwencji osoby trzeciej. Juryści włoscy opracowali trzy cechy konstytutywne usiłowania, które musiały wystąpić łącznie, aby mogła być o nim mowa. Były to: zły zamiar (cogitare), przystąpienie do działania, to jest czynności przygotowawcze (agere), oraz niedoprowadzenie do skutku (non perficere; non perducere ad effectum) ${ }^{30}$.

$\mathrm{Na}$ tym tle w XIV wieku na podstawie prawa statutowego rozwinęła się nauka o różnych stopniach usiłowania: oddalonym (conatus remotus), bliskim (propinquus) i najbliższym (proximus). Doktryna, czerpiąc z kazuistycznych przepisów statutowych, sformułowała abstrakcyjną propozycję prawną, zgodnie z którą wysokość kary powinna opierać się na dystansie między czynnością przygotowawczą a dokonaniem ${ }^{31}$. Stanowiły one w istocie stadia czynu przestępnego, składającego się na pojęcie karalnego usiłowania, chociaż nie były wówczas tak postrzegane. Łatwiej tę teoretyczną konstrukcję zrozumieć za pomocą przykładów. W przypadku usiłowania zabójstwa conatus proximus stanowić miało fizyczne zranienie zaatakowanej osoby, natomiast sam atak to conatus propinquus, udanie się na miejsce zamachu z bronią lub przygotowanie do otrucia uważano za

27 Por. omówienie osiągnięć prawa statutowego w tym zakresie: A. Gaca, Z. Filipiak, Prawo statutowe włoskie i jego wplyw na rozwój europejskiego prawa sądowego, [w:] Miasto..., s. 20.

28 K. Koranyi, Powszechna historia państwa i prawa, t. 3, Warszawa 1966, s. 92.

29 M. Patkaniowski, Wina..., s. 86.

30 K. Sójka-Zielińska, op. cit., s. 177.

31 G. Dahm, Das Strafrecht Italiens im ausgehenden Mittelalter. Untersuchungen über die Beziehungen zwischen Theorie und Praxis im Strafrecht des Spätmittelalters, namentlich im XIV. Jahrhundert, Berlin-Lipsk 1931, s. 194. 
conatus remotus. W wypadku zgwałcenia pchnięcie kobiety na ziemię było usiłowaniem bliskim, zaś całowanie czy dotykanie — oddalonym ${ }^{32}$.

Usiłowanie najbliższe, co do zasady, odpowiadało dokonaniu, z wyjątkiem przepisów, które zachowały podział na karę cielesną i kompozycję pieniężną. Czynności i sytuacje zaliczane do usiłowania bliskiego i wskazujące jednoznacznie na zły zamiar były w niektórych statutach karane, w przeciwieństwie do conatus remoti, które albo nie powodowały odpowiedzialności karnej, albo kwestię rozstrzygnięcia pozostawiały uznaniu sędziego. W zakresie podziału na przestępstwa publiczne i prywatne (za prawem rzymskim) uzgodniono communis opinio, iż usiłowanie tych ostatnich nie powinno być karane. Wśród legistów popularne było także rozróżnienie na przestępstwa lekkie (levis) i ciężkie (delicta atrocia). Niektórzy uczeni (na przykład Jacobus de Belviso, Albericus de Rosate) postulowali, aby ograniczyć odpowiedzialność za usiłowanie do przestępstw ciężkich ${ }^{33}$. $\mathrm{Z}$ reguły bezkarne pozostawało usiłowanie, gdy sprawca dobrowolnie nie doprowadził do skutku, chyba że szkoda już nastąpiła.

\section{Przykłady}

W początkowym okresie rozwoju komuny prawo statutowe nie ujmowało usiłowania jako czynności polegających na dążeniu do wypełnienia znamion jakiejś poważniejszej zbrodni, lecz ujmowało je jako delicta sui generis, posługując się bardzo kazuistycznym opisem ${ }^{34}$. Zatem nie mamy jeszcze do czynienia z wykształconym pojęciem. Do takich czynów najczęściej należały: groźba użycia przemocy, noszenie lub wyciągnięcie broni, uszkodzenie ciała bez utraty krwi bądź innego skutku, pozyskiwanie i podawanie trucizny, gromadzenie ludzi, wywoływanie niepokojów społecznych, uszkodzenie wejścia lub wtargnięcie do cudzego domu ${ }^{35}$.

Przepis ne quis vadat ad aliquod guarnimentum, wymieniając szczegółowo podmioty przestępstwa (rycerz, piechur, łucznik, kusznik), zabraniał im zwoływania na obszarze jurysdykcji Vicenzy (to jest miasto i obszary wiejskie) nielegalnego zgromadzenia ludzi uzbrojonych dla dokonania ataku, pod groźbą grzywny zróżnicowanej odpowiednio według statusu społecznego (dla rycerza 50 lirów, dla piechura -20 , a dla strzelców -5 ), natomiast w przypadku nieuiszczenia grzywny - dożywotniej banicji ${ }^{36}$.

32 Ibidem.

33 Ibidem, s. 195.

${ }^{34}$ M. Patkaniowski, Wina ..., s. 84.

35 G. Dahm, op. cit., s. 187.

36 Statuti del comune di Vicenza, [w:] Monumenti storici pub. dalla R. Deputazione veneta di storia patria. Serie seconda. Statuti, t. 1, Venezia 1886, s. 129. 
Podobny stan faktyczny przedstawiono w statucie komuny Vertova z 1235 ro$\mathrm{ku}$. Przepis de non ire in aliquo invitamento cum armis vetatis zabraniał mieszkańcom gminy udziału w zgromadzeniu $\mathrm{z}$ bronią w ręku lub w celu zdobycia broni bez specjalnego pozwolenia od władz miasta, pod sankcją grzywny 5 soldów ${ }^{37}$. Statut Turynu z 1360 roku surowo postanawiał, że kto przybędzie do miasta z zamiarem zabicia lub zranienia jakiegoś obywatela, ma ponieść karę śmierci ${ }^{38}$. Według statutu Pizy z 1286 roku na tego, kto przekupił lub chciał przekupić podestę lub jednego z jego sędziów czy żołnierzy, nakładało się karę grzywny od 10 do 100 lirów. Dokładna jej wysokość została pozostawiona uznaniu sędziego, który powinien kierować się osobą i charakterem czynności sprawcy ${ }^{39}$.

Klasyczna instytucja usiłowania zaczęła pojawiać się dopiero w XIV wieku. Nie przyjęła wszakże normy o charakterze ogólnym, lecz odnosiła się do szczegółowych przestępstw, przy których statut zaznaczał, że usiłowanie jest karalne. $\mathrm{Z}$ reguły do usiłowania statuty odnosiły się za pomocą kilku wyrażeń ogólnych. Najbardziej typowym było określenie velle. Często pojawiały się również terminy temptare, attentare, attemptare, rzadziej conari i conatus. Gdzieniegdzie znaleźć można słowo presumere $e^{40}$.

Często zastrzeżenie takie pojawiało się przy przestępstwie zgwałcenia (stuprum, carnaliter cognoscere). Wiązało się to także ze szczególną ochroną dobra, jakim w średniowieczu była cześć niewiasty. Statut komuny Casale z lat 1370-1400 próbę odbycia stosunku seksualnego z dziewicą bądź czyjąś żoną karał grzywną w wysokości 100 lirów, natomiast zgwałcenie lub próbę zgwałcenia kobiety cieszącej się dobrą sławą karał śmiercią.

Według statutu Vallassiny z 1342 roku zgwałcenie groziło śmiercią, a usiłowanie zgwałcenia - grzywną w wysokości 10 lirów. Podobnie postanawiał statut komuny Mandello ${ }^{41}$. Statut komuny Bellano z 1370 roku sankcjonował przestępstwo zgwałcenia, zarówno dokonane, jak i usiłowane, grzywną 25 lirów. Opisał przy tym bardzo dokładnie czynności uzewnętrzniające zamiar, które świadczą o zaistnieniu usiłowania, takie jak rzucenie kobiety na ziemię, szarpanie za jej suknię czy intrando in eius tibiis ${ }^{42}$. Bardzo podobnie w tym względzie stanowił jeden z przepisów statutu Vergante z 1389 roku. Statut Bielli (małej komuny w Piemoncie) za zgwałcenie groził karą śmierci. Gdyby jednak skutek nie nastąpił, przez okoliczności niezależne od sprawcy, musiał on zapłacić grzywnę w wysokości 500 lirów, pod warunkiem, że usiłowanie było najbliższe (actus proximus $)^{43}$.

\footnotetext{
37 Statuti di Vertova del 1235, del 1248, del 1256, Brescia 1869, s. 13.

38 M. Patkaniowski, Wina..., s. 85.

39 Statuti inediti della città di Pisa dal XII al XIV secolo, t. 1, Firenze 1854, s. 459.

40 G. Dahm, op. cit., s. 189.

41 M. Patkaniowski, Wina..., s. 86.

42 Statuti di Bellando e Mandello, Mediolan 1932, s. 305.

43 G. Dahm, op. cit., s. 197.
} 
Podobnie jak w przypadku poprzednich ustawodawstw trucicielstwo (veneficium, venenum dare) było obszarem, w którym instytucja usiłowania okazała się potrzebna. Statut komuny Aspra Sabina z 1397 roku (jeden z nielicznych spisanych w języku włoskim) przewidywał karę w wysokości 50 złotych florenów w stosunku do osoby, która chciała otruć drugiego, a spodziewana śmierć nie nastąpiła.

Przy przestępstwie kradzieży (furtum) zwracano niekiedy uwagę nie tylko na czynności przygotowawcze bezpośrednio zmierzające do dokonania, lecz także na bardziej oddalone przesłanki świadczące o przestępnym zamiarze (voluntas sceleris). Interesującą dyspozycję przedstawiał przepis statutu komuny Valsassina. Zrównywał on posiadanie wytrychów i innych narzędzi przeznaczonych do włamań z przyłapaniem na gorącym uczynku kradzieży. Obie sytuacje były wystarczającym uzasadnieniem dla poddania sprawcy torturom bądź przesłucha$\mathrm{niu}^{44}$. Przepis ten stanowił jeden z przykładów karania conatus remotus.

Zdarzało się, że statuty penalizowały usiłowanie spędzenia płodu, określanego jako istota ludzka nienarodzona. Często w tym wypadku odpowiedzialność była surowa i zrównana z dokonaniem, bez względu na to, czy czynności zostałyby podjęte chociażby w błędnym przeświadczeniu o zaistnieniu ciąży. Przykładowo przepis statutu komun Vergante, Lesa i Meina postanawiał, iż kobieta, która w zamiarze spowodowania poronienia wypiła lub zjadła jakąś substancję, karana miała być tak samo jak za dokonanie aborcji - przez spalenie na stosie ${ }^{45}$.

Statuty wielu miast szczegółowo przewidywały czyny popełniane przez najemnego zabójcę (assassinus). Wiązało się to między innymi z powszechnością występowania tego typu działalności w owym czasie oraz z tym, że łatwiej było rozpoznać konkretny zamiar zawodowca wykonującego zlecenie. Wedle statutu Bielli najemny morderca karany był powieszeniem, jeśli ofiara umarła, w przeciwnym razie musiał zapłacić 1000 lirów. Jeśli sprawca nie zapłacił grzywny, tracił prawą rękę. Statut Bassano z 1392 roku również wobec zabójcy najemnego przewidywał karę mutylacyjną w postaci obcięcia obu rąk, jeżeli nastąpił skutek śmiertelny lub sprawca zranił ofiarę, działając w zamiarze zabójstwa (animo occidendi). Natomiast jeśli chciał daną osobę tylko zaatakować bez wywoływania skutku śmiertelnego, tracił jedną rękę. Na przykładzie przepisu statutu Padwy z 1366 roku, dotyczącego zleconych zabójstw, można szczególnie wyraźnie zaobserwować wpływ doktryny ${ }^{46}$. Jeśli ofiara umarła, najemny zabójca i zlecający mieli być wleczeni, przez przywiązanie do końskiego ogona, i powieszeni bądź spaleni żywcem. Jeżeli śmierć nie nastąpiła, a zabójca popełnił czyny zaliczane do usiłowania najbliższego (acti proximi), czekała go taka sama kara. Natomiast

44 Statuti della Valsassina dell'anno 1388, [w:] Corpus Statutorum Italicorum, t. 3, Rome 1913, s. 318.

45 M. Patkaniowski, Wina..., s. 88.

${ }^{46}$ G. Dahm, op. cit., s. 198. 
gdyby dopuścił się tylko czynów usiłowania oddalonego (acti remoti), tracił oczy i jedną rękę.

W niektórych przepisach za usiłowanie groziła taka sama kara jak za dokonanie. Jednakże często statuty pozostawiały sędziom swobodę uznania ${ }^{47}$. Jedną z przesłanek złagodzenia kary było niedojście zbrodni do skutku ${ }^{48}$. Dlatego w większości przypadków zdarzało się, że kara za usiłowanie w praktyce była obniżana.

Statuty nie znały pojęcia usiłowania nieudolnego. Mimo tego znaleźć w nich można kazusy przypominające $\mathrm{w}$ pewien sposób nowożytne pojmowanie tej kwestii, chociażby wspomniane wyżej przepisy statutów Vergante, Lesy i Meiny. W statucie Valsoldy z 1388 roku znajdował się przepis, zgodnie z którym miała być ukarana kobieta, która rzucała przekleństwa na inną osobę i na klęczkach prosiła Boga o jej śmierć. Gdyby nie fakt, że ówczesna teoria nie znała tego pojęcia, można by określić tę sytuację jako usiłowanie bezwzględnie nieudolne ${ }^{49}$.

\section{Podsumowanie}

$\mathrm{Na}$ styku dwóch kultur prawnych, przy udziale bezprecedensowej formy ustrojowej, wypracowano, jak na owe czasy, koncepcję usiłowania zaskakująco interesującą i zaawansowaną. Rzecz jasna, nie można porównywać jej z nowoczesną teorią, która pojawiła się dopiero w XIX wieku. Statuty ani praktyka miast włoskich nie odróżniały przygotowania od usiłowania, zatem pojęcie czynności przygotowawczych rozumiano bardzo szeroko. Brak także w statutach jakichkolwiek ogólnych przepisów dotyczących usiłowania mających zastosowanie do całej ustawy karnej.

Dzięki działaniom doktryny i judykatury ugruntowała się zasada braku odpowiedzialności za sam zamysł (nuda cogitatio). Sformułowanie teorii o trzech stopniach usiłowania ułatwiło przeprowadzanie dowodów w oparciu o konkretne czynności dostatecznie uzewnętrzniające zamiar oraz w pewnym stopniu sprecyzowało, które czynności przygotowawcze niewątpliwie mogły zostać zakwalifikowane jako karalne usiłowanie. Z drugiej strony, uzależnienie wymiaru kary od etapu usiłowania, postulowane przez doktrynę, spowodowało, że w przeważającej części przykładów nie było ono karane jednolicie ani na równi z dokonaniem.

Jednakże należy podkreślić, iż to w ustawodawstwie statutowym miast włoskich po raz pierwszy w historii prawa karnego pojawiła się, jako zasada powszechnie stosowana, karalność usiłowania popełnienia przestępstwa. Szeroka gama typów czynów zabronionych przewidywała ich usiłowanie nie jako przestępstwa

\footnotetext{
47 Ibidem, s. 190.

48 G. Salvioli, op. cit., s. 559.

49 M. Patkaniowski, Wina ..., s. 43.
} 
sui generis, lecz raczej na kształt formy stadialnej. Był to duży krok na drodze do współczesnej koncepcji iter delicti (pochodu przestępstwa).

Artykuł ten stanowić może przyczynek do pogłębionych badań nad zjawiskiem zastąpienia delicta sui generis przez formy stadialne realizacji znamion czynu zabronionego. Pierwsze z wymienionych miały charakter przestępstw formalnych chroniących inne dobro prawne niż to, które narusza skutek lub chroniących to samo dobro na przedpolu jego naruszenia. Celem dalszej pracy badawczej nad źródłami powinno być także bliższe określenie przyczyn, z powodu których w czternastowiecznych miastach północnej Italii ustawodawcy, przy wsparciu doktryny, zdecydowali o konieczności penalizacji usiłowania popełnienia niektórych przestępstw.

\section{Bibliografia}

\section{Źródła drukowane}

Statuti del comune di Vicenza 1264, [w:] Monumenti storici pub. dalla R. Deputazione veneta di storia patria. Serie seconda. Statuti, t. 1, Venezia 1886.

Statuti della Valsassina dell'anno 1388, [w:] Corpus Statutorum Italicorum, t. 3, Rome 1913.

Statuti di Mandello del secolo XIV, [w:] Statuti di Bellando e Mandello, Mediolan 1932.

Statuti di Vertova del 1235, del 1248, del 1256, Brescia 1869.

Statuti inediti della città di Pisa dal XII al XIV secolo, t. 1, Firenze 1854.

\section{Literatura}

Amielańczyk K., Lex Cornelia de sicariis et veneficis. Ustawa Korneliusza Sulli przeciwko nożownikom i trucicielom 81 r.p.n.e., Lublin 2011.

Calasso F., Medio evo del diritto: I - de fonti, Mediolan 1954.

Caravale M., Ordinamenti giuridici dell'Europa medievale, Bolonia 2003.

Dahm G., Das Strafrecht Italiens im ausgehenden Mittelalter. Untersuchungen über die Beziehungen zwischen Theorie und Praxis im Strafrecht des Spätmittelalters, namentlich im XIV. Jahrhundert, Berlin-Lipsk 1931.

D'Anello A., La rilevanza degli atti preparatori in materia penale, Neapol 2013.

Estreicher S., Historia prawa zachodnio-europejskiego: źródła, Kraków 1946.

Gaca A., Filipiak Z., Prawo statutowe włoskie i jego wptyw na rozwój europejskiego prawa sadowego, [w:] Miasto i państwo na przestrzeni dziejów, studium historyczno-prawne: księga jubileuszowa z okazji czterdziestopięciolecia pracy naukowej oraz 70. urodzin profesora Tadeusza Maciejewskiego, red. M. Gałędek, Warszawa 2020.

Gierowski J.A., Historia Włoch, Wrocław-Warszawa-Kraków-Gdańsk-Łódź 1986.

Jurkowska-Zeidler A., Zeidler K., Medyceusze jako bankierzy oraz mecenasi i kolekcjonerzy sztuki, [w:] Miasto i państwo na przestrzeni dziejów, studium historyczno-prawne: księga jubileuszowa z okazji czterdziestopięciolecia pracy naukowej oraz 70. urodzin profesora Tadeusza Maciejewskiego, red. M. Gałędek, Warszawa 2020.

Kamińska K., Gaca A., Historia powszechna ustrojów państwowych, Torun 2011. 
Koranyi K., Powszechna historia państwa i prawa, t. 2, cz. 1, Warszawa 1963.

Koranyi K., Powszechna historia państwa i prawa, t. 3, Warszawa 1966.

Maciejewski T., Historia powszechna państwa i prawa, Warszawa 2000.

Manikowska H., Średniowieczne miasta-państwa na Pótwyspie Apenińskim, [w:] Rozkwit średniowiecznej Europy, red. H. Samsonowicz, Warszawa 2001.

Miasto i państwo na przestrzeni dziejów, studium historyczno-prawne: księga jubileuszowa z okazji czterdziestopięciolecia pracy naukowej oraz 70. urodzin profesora Tadeusza Maciejewskiego, red. M. Gałędek, Warszawa 2020.

Padoa-Schioppa A., Il diritto nella storia d'Europa. Il medioevo, t. 1, Mediolan 2005.

Padoa-Schioppa A., Storia del diritto in Europa. Dal medioevo all'età contemporanea, Bolonia 2007.

Patkaniowski M., Charakterystyka ustawodawstwa statutowego na tle rozwoju komuny wtoskiej, „Czasopismo Prawnicze” 31, 1938.

Patkaniowski M., Wina i kara. Elementy rzymskie i germańskie w prawie karnym statutów włoskich, Kraków 1939.

Ptaśnik J., Miasta i mieszczaństwo w dawnej Polsce, Kraków 1934.

Sadowski P., Rzymskie prawo karne w ujęciu Contarda Ferriniego, „Studia Prawnoustrojowe” 2007, $\mathrm{nr} 7$.

Salvioli G., Manuale di storia del diritto italiano: dalle invasione germaniche ai nostri giorni, Rome-Torino-Neapol 1890.

Sójka-Zielińska K., Historia prawa, Warszawa 2001.

Storia del diritto medievale e moderno, red. R.M. Venittelli, Neapol 2002.

\section{The notion of punishable attempt in doctrine and statutory law of Italian cities $\left(13^{\text {th }}-14^{\text {th }}\right.$ century)}

\section{Summary}

The purpose of the article is organising the past knowledge about criminal liability of the intent to commit a criminal offence. The legal construction of first offences formed in the statutes passed by Italian cities from the thirteenth to the fourteenth century. The possibility of an unfettered enactment of these legal acts was related to the autonomy of peculiar state structures - urban communes. In statutory law the elements of Roman and Lombard law articulated one another. However, these previous legal systems did not yet know the liability for attempting to commit crime as a general rule. A major influence on the activity of urban legislators was exerted by the notions framed by contemporary jurists, concerning themselves with the theoretical grounds for the institution of attempted crime. The author gives instances of legal rules, originating from the statutes of various communes, which proclaim that the intent to commit an unlawful act was punishable, despite the act itself not being committed.

Keywords: history of criminal law, attempted crime, statutory law, medieval Italian cities. 


\section{Der Begriff eines strafbaren Versuchs in der Doktrin und in der Gesetzgebung der italienischen Städte (13.-14. Jahrhundert)}

\section{Zusammenfassung}

Ziel des Beitrags ist, das bisherige Wissen über die strafrechtliche Verantwortlichkeit des Vorsatzes zur Begehung einer Straftat zu organisieren. Die Konstruktion des Versuchs ein Verbrechen zu begehen, erschien zum ersten Mal in den im 13. und 14. Jahrhundert durch die italienischen Städte erlassenen Statuten. Die Möglichkeit einer ungehinderten Entstehung dieser Rechtsakte war auf die Autonomie der eigenartigen institutionellen Form - der Stadtkommunen zurückzuführen. In der Satzungsgesetzgebung verbanden sich Elemente des römischen und des langobardischen Rechts miteinander. Diese früheren Rechtssysteme kannten jedoch grundsätzlich die Verantwortlichkeit für verbrecherischen Vorsatz noch nicht. Großen Einfluss auf die Tätigkeit der städtischen Gesetzgeber übten die Ansichten der damaligen Juristen aus, die sich mit der theoretischen Begründung der Institution des Versuchs befassten. Der Autor stellt Beispiele der Vorschriften dar, die den Statuten verschiedener Kommunen zu entnehmen sind und die von der Strafbarkeit eines Versuchs, eine Straftat zu begehen, ohne dass diese vollendet wurde, zeugen.

Schlüsselwörter: Geschichte des Strafrechts, Versuch, Satzungsrecht, mittelalterliche italienische Städte. 